\title{
Perbandingan Efek Pemberian Emulsi Kedelai dan Emulsi Tempe Terhadap Hitung Limfosit Total pada Tikus Putih yang Telah Diberi Prednison
}

\author{
Rizka Bekti Nurcahyani, Imelda T Pardede, Huriatul Masdar"
}

\begin{abstract}
Adequate nutrition is one of important factors in immunodeficiency repairment. Soybean and tempeh contains proteins, zinc, ferrum, vitamins and isoflavon. Fermentation in tempeh makes it having better nutrients digestion and absorption than soybean. The objective of this study was to compare the effects of soy and tempeh emulsions on total lymphocyte count in rats treated with prednisone. The test was done on 24 male white rats divided into four groups. Group A was given distilled water and group B, C and D had prednisone $2.5 \mathrm{mg} /$ day for 6 days. After that, group A and B were continued having distilled water while groups $\mathrm{C}$ or $\mathrm{D}$ was fed with soy or tempeh emulsion $0.71 \mathrm{~mL} /$ day for 10 days, respectively. The results shown that soy and tempeh emulsion could increase total lymphocyte count significantly $(\mathrm{p}<$ $0,05)$ but there was no significant difference of total lymphocyte count between soy and tempeh emulsion groups $(\mathrm{p}>$ $0,05)$.
\end{abstract}

Key words: soybean, tempeh, total lymphocyte count, prednisone.

Lingkungan di sekitar manusia mengandung berbagai jenis patogen yang dapat menyebabkan infeksi misalnya bakteri, virus, jamur, protozoa dan parasit. Infeksi yang terjadi pada orang normal umumnya singkat dan jarang meninggalkan kerusakan permanen. Hal ini disebabkan tubuh manusia memiliki suatu sistem yang disebut sistem imun. Sistem imun terdiri atas sistem imun spesifik dan non-spesifik. Sel limfosit merupakan sel yang berperan utama dalam sistem imun spesifik. ${ }^{1,2}$

Penurunan atau gagalnya fungsi dari salah satu atau lebih unsur sistem imun disebut imunodefisiensi. Kegagalan fungsi ini sering berkaitan dengan gagalnya kerja limfosit, komplemen dan fagosit. ${ }^{1}$ Prednison termasuk obat steroid golongan glukokortikoid penyebab imunodefisiensi sekunder. ${ }^{3}$ Pemberian dosis tunggal glukokortikoid dengan masa kerja pendek akan menurunkan jumlah limfosit dalam sirkulasi. ${ }^{3,4}$

\footnotetext{
* corresponding address: Histology Department Facultyof Medicine Riau University

Jalan Diponegoro 1 Pekanbaru, Riau 28111

Email: dr_huriatul@yahoo.co.id
}

Penggunan prednison ini telah banyak digunakan pada penelitian untuk memperoleh model hewan yang mengalami penekanan sistem imun. ${ }^{5,6}$

Pemberian nutrisi yang adekuat adalah salah satu faktor yang berperan penting dalam perbaikan imunodefisiensi. . $, 7,8$ Penelitian yang dilakukan oleh Bloom et al yang dikutip dari Usman menunjukkan bahwa pada kelompok tikus yang diberi diet rendah protein terjadi penurunan status imunologi dan setelah diberi diet tinggi protein dapat berubah kembali seperti kelompok tikus yang dari awal diberi diet tinggi protein. ${ }^{7}$

Kedelai (Glycine max) merupakan bahan makanan sumber protein yang tinggi ${ }^{9,10}$ dan mengandung nutrien lain yang dapat membantu meningkatkan sistem imun, di antaranya adalah vitamin (vitamin A, C, E dan B6) ${ }^{8}$, mineral (Zn dan $\mathrm{Fe})^{8,11,12}$ dan isoflavon..$^{13,14,15}$ Tempe yang berasal dari kedelai yang difermentasi oleh jamur Rhizopus sp juga sangat kaya akan protein, vitamin, mineral dan isoflavon. ${ }^{16,17,18}$

Tempe memiliki beberapa keunggulan dibandingkan kedelai. Proses fermentasi pada tempe 
menghasilkan enzim protease dan fitase yang menyebabkan pencernaan dan penyerapan nutriennutrien tersebut oleh tubuh menjadi lebih baik. ${ }^{16,17}$ Tempe juga diketahui mengandung vitamin B12 yang juga berperan dalam meningkatkan jumlah leukosit. ${ }^{9,16}$

Berdasarkan uraian diatas peneliti tertarik untuk meneliti efek pemberian emulsi kedelai (Glycine max) dan emulsi tempe terhadap hitung limfosit total pada tikus putih (Rattus norvegicus) yang telah ditekan sistem imunnya dengan menggunakan prednison.

Adapun tujuan dari penelitian ini adalah untuk mengetahui perbandingan efek pemberian emulsi kedelai dan emulsi tempe terhadap hitung limfosit total pada tikus putih yang telah diberi prednison.

\section{METODE}

Penelitian ini merupakan penelitian eksperimental laboratorik dengan post test only control group design yang dilakukan pada bulan November - Desember 2010 di Laboratorium Histologi Fakultas Kedokteran Universitas Riau.

Penelitian ini menggunakan 24 ekor tikus putih (Rattus norvegicus) jantan strain Wistar umur 2-3 bulan dengan berat badan rata-rata 150-250 gram dan memenuhi kriteria hewan uji sehat. Hewan uji dikatakan sehat apabila penampilan fisik tidak tampak kurus, bentuk badan simetris, bergerak gesit, berat badan selama proses adaptasi tidak menurun lebih dari $10 \%$ berat badan semula.

Kedelai yang digunakan pada penelitian ini adalah kedelai yang terdapat di pabrik tempe dengan merk Cap Kunci Mas produksi PGEO Edible Oils SDN BHD Malaysia. Sedangkan tempe yang digunakan berasal dari fermentasi kedelai yang sama dengan yang akan dijadikan emulsi kedelai. Kedelai dan tempe dibuat menjadi tepung dan kemudian dibuat emulsi dengan metode kontinental kering dengan perbandingan minyak:air:gom adalah 10 mL:90 mL:4,37245 gram.

Sebelum memulai perlakuan seluruh hewan coba diadaptasikan di lingkungan yang baru selama satu minggu dan diberi makan dan minum ad libitum. Setelah adaptasi hewan coba dibagi dalam empat kelompok perlakuan. Kelompok A diberi aquadest sementara kelompok B, C dan D diberi prednison 2,5 $\mathrm{mg} / \mathrm{ekor} / \mathrm{hari}$ selama enam hari. Kemudian kelompok A dan B dilanjutkan dengan pemberian aquadest, kelompok $\mathrm{C}$ dilanjutkan dengan pemberian emulsi kedelai $0,71 \mathrm{~mL} / \mathrm{ekor} / \mathrm{hari}$ selama 10 hari dan kelompok D dilanjutkan dengan pemberian emulsi kedelai dengan dosis dan lama perlakuan yang sama. Pemberian perlakuan dilakukan dengan pencekokan menggunakan sonde hewan. Selama perlakuan hewan coba tetap diberi pakan standar yaitu pelet 782 dengan kandungan protein $\pm 18 \%$.

Setelah 6 hari pemberian prednison, seluruh hewan coba diambil darahnya dengan memotong ujung ekornya sepanjang $1 \mathrm{~cm}$ dari ujung. Kemudian dilakukan penghitungan limfosit total untuk membuktikan efek prednison dalam menurunkan hitung limfosit total tikus. Darah seluruh tikus kembali diambil dari ekor yang dipotong sepanjang $0,5 \mathrm{~cm}$ dari ujung ekor setelah 10 hari pemberian emulsi kedelai dan emulsi tempe. ${ }^{20}$ Kemudian dilakukan kembali penghitungan limfosit total.

Penghitungan limfosit total dilakukan dengan melakukan perkalian persentase limfosit dengan jumlah leukosit total. ${ }^{21}$ Persentase limfosit dilihat menggunakan sediaan apus darah pewarnaan Giemsa (duplo). Jumlah leukosit total didapat dari jumlah leukosit yang tampak pada kamar hitung Improved Neubauer yang dikalikan 50.

Data diolah dan dianalisis secara komputerisasi dengan menggunakan program SPSS 16. Data yang diperoleh setelah pemberian prednison dianalisis menggunakan uji $\mathrm{T}$ tidak berpasangan dan data yang diperoleh setelah pemberian perlakuan dengan emulsi tepung tempe dan kedelai dianalisis menggunakan uji One Way Anova. ${ }^{22}$

\section{HASIL}

Penelitian ini menghasilkan data hitung limfosit total atau Total Lymphocyte Count (TLC) pada 4 kelompok perlakuan yaitu kelompok A, B, C dan D. Setelah perlakuan pemberian prednison selama 6 hari dan 10 hari pemberian emulsi kedelai dan emulsi tempe, didapatkan rerata hitung limfosit total pada ke-4 kelompok seperti yang tertera pada tabel 1 . 
Tabel 1. Rerata hitung limfosit total setelah 6 hari pemberian prednison dan setelah 10 hari pemberian emulsi tepung tempe atau tepung kedelai

\begin{tabular}{|c|c|c|c|}
\hline \multirow[t]{2}{*}{ Kelompok } & \multirow[t]{2}{*}{ Keterangan } & \multicolumn{2}{|c|}{$\begin{array}{l}\text { Hitung Limfosit Total } \\
\left(\text { Mean } \pm \text { SD }\left(\mathrm{sel} / \mathrm{mm}^{3}\right)\right)\end{array}$} \\
\hline & & $\begin{array}{c}\text { Post predison } \\
6 \text { hari }\end{array}$ & $\begin{array}{l}\text { Post tempe atau } \\
\text { kedelai } 10 \text { hari }\end{array}$ \\
\hline A & Aquadest & $2637,33 \pm 210,83$ & $3031,31 \pm 510,93$ \\
\hline B & Prednison+ Aquadest & $715,46 \pm 178,72$ & $1372,98 \pm 289,51$ \\
\hline $\mathrm{C}$ & Prednison+Emulsi Kedel ai & $412,75 \pm 143,90$ & $3944,25 \pm 601,27$ \\
\hline D & Prednison+Emul si Tempe & $384,79 \pm 262,31$ & $3851,52 \pm 586,69$ \\
\hline
\end{tabular}

Hasil analisis data setelah 6 hari pasca pemberian prednison dengan menggunakan uji $\mathrm{T}$ tidak berpasangan menunjukkan terdapat perbedaan bermakna hitung limfosit total antara kelompok yang diberi prednison dengan yang tidak diberi prednison $(\mathrm{p}=0,000)$. Hal ini menunjukkan bahwa prednison yang diberikan telah cukup untuk menekan sistem imun pada hewan coba.

Selanjutnya, hasil analisis data hitung limfosit total setelah 10 hari pemberian emulsi tepung tempe dan tepung kedelai dengan menggunakan uji One Way Anova menunjukkan paling tidak terdapat dua kelompok yang hitung limfosit totalnya berbeda secara bermakna $(\mathrm{p}=0,000)$. Kemudian data dianalisis lebih lanjut dengan analisis Post Hoc dan didapatkan hasil seperti tertera pada tabel 2.

Tabel 2. Analisis Post Hoc pada empat kelompok perlakuan.

\begin{tabular}{ccccc}
\hline Kelompok & A & B & C & D \\
\hline A & - & 0,000 & 0,006 & 0,012 \\
B & & - & 0,000 & 0,000 \\
C & & & - & 0,772 \\
\hline
\end{tabular}

\begin{tabular}{lllll}
\multicolumn{2}{l}{ Kelompok A } & B & C & D \\
A - & 0,000 & 0,006 & 0,012 \\
B & - & 0,000 & 0,000 \\
C & & - & & 0,772
\end{tabular}

Analisis Post Hoc menunjukkan bahwa hampir antara semua kelompok terdapat perbedaan yang bermakna, kecuali kelompok $\mathrm{C}$ dengan kelompok $\mathrm{D}(\mathrm{p}=0,772)$. Kelompok $\mathrm{C}$ adalah kelompok tikus yang diberi emulsi kedelai dan kelompok D adalah kelompok tikus yang diberi emulsi tempe. Dapat disimpulkan bahwa tidak terdapat perbedaan bermakna antara kelompok tikus yang diberi emulsi kedelai dengan kelompok tikus yang diberi emulsi tempe. Meskipun begitu kelompok yang diberi emulsi kedelai maupun yang diberi emulsi tempe berbeda bermakna dengan kelompok kontrol yaitu kelompok B. Hal tersebut menunjukkan bahwa emulsi kedelai dan emulsi tempe berefek meningkatkan hitung limfosit total pada tikus putih jantan yang telah diberi prednison.

\section{PEMBAHASAN}

Pada hasil penelitian diatas terlihat pemberian prednison secara nyata dapat menekan sistem imun yang salah satunya ditandai dengan penurunan jumlah hitung limfosit total pada hewan coba. Hitung limfosit total pada kelompok A yang tidak diberi prednison berbeda bermakna $(p=0,000)$ dengan kelompok B, C dan $\mathrm{D}$ yang diberi prednison dengan dosis 2,5 mg/hari selama 6 hari. Hal ini sesuai dengan penelitian Katrin et al dan Prasetya yang juga menggunakan prednison dengan dosis masing-masing $3,5 \mathrm{mg} / \mathrm{kgBB} / \mathrm{hari}$ dan $0,9 \mathrm{mg} /$ $35 \mathrm{grBB} /$ hari untuk menekan sistem imun hewan coba untuk mendapatkan hewan coba imunodefisiensi. ${ }^{5,6}$ Meskipun dosis yang digunakan berbeda, namun dengan dosis $2,5 \mathrm{mg} /$ hari yang merupakan dosis konversi dari manusia ke tikus untuk indikasi imunosupresan telah terbukti dapat menurunkan hitung limfosit total pada tikus putih jantan secara bermakna. ${ }^{3}$

Mekanisme prednison menurunkan hitung limfosit total pada tikus yaitu dengan menyebabkan destruksi jaringan limfoid yang ditandai dengan 
penurunan berat kelenjar timus dan limpa ${ }^{23}$ serta menyebabkan penurunan jumlah dan diameter germinal center kelenjar getah bening ${ }^{24}$. Kelenjar timus merupakan tempat maturasi dan diferensiasi sel limfosit $\mathrm{T}$ sedangkan limpa adalah jaringan limfoid sekunder tempat proliferasi limfosit. ${ }^{1}$ Germinal center merupakan tempat berlangsungnya proliferasi dan diferensiasi limfosit B menjadi sel plasma. ${ }^{24}$ Penelitian yang dilakukan oleh Lanza et al juga menunjukkan bahwa prednison menyebabkan apoptosis pada sel limfosit $\mathrm{T}$ di perifer. ${ }^{25}$ Mekanisme-mekanisme tersebut yang menyebabkan hitung limfosit total pada tikus putih jantan yang diberi prednison lebih rendah dibandingkan yang tidak diberi prednison.

Pada penelitian ini juga didapatkan hasil bahwa kelompok tikus yang diberi emulsi kedelai dan emulsi tempe setelah ditekan sistem imunnya dengan prednison hitung limfosit totalnya berbeda bermakna dengan kelompok tikus yang diberi prednison dan kemudian hanya diberi aquadest. Kelompok $\mathrm{C}$ yang diberi emulsi kedelai berbeda bermakna $(\mathrm{p}=0,000)$ dengan kelompok $\mathrm{B}$ yang diberi aquadest. Begitupun kelompok D yang diberi emulsi tempe dengan kelompok $\mathrm{B}$ berbeda secara bermakna $(\mathrm{p}=0,000)$. Disini terlihat bahwa pemberian emulsi kedelai dan emulsi tempe dengan dosis $0,71 \mathrm{~mL} /$ hari yang mengandung tepung kedelai dan tepung tempe $10 \mathrm{mg}$ selama 10 hari dapat meningkatkan hitung limfosit total pada tikus putih yang telah ditekan sistem imunnya menggunakan prednison.

Hal tersebut terjadi karena kedelai dan tempe memiliki kandungan nutrien yang dapat menyebabkan peningkatan sistem imun. Kedelai dan tempe mengandung protein yang tinggi. ${ }^{9,16} \mathrm{Hal}$ ini sesuai dengan penelitian yang dilakukan oleh Bloom et al bahwa pada kelompok tikus yang diberi diet rendah protein terjadi penurunan status imunologi dan setelah diberi diet tinggi protein terjadi peningkatan status imunologi menjadi seperti kelompok tikus lainnya yang diberi diet tinggi protein sejak awal. ${ }^{7}$

Kedelai dan tempe juga mengandung mineralmineral yang berpengaruh terhadap peningkatan sistem imun seperti $\mathrm{Zn}$ dan Fe. ${ }^{9}, 16$ Penelitian yang dilakukan oleh Winarsi et al pada kelompok wanita pre menopause yang diberi suplementasi $\mathrm{Zn}$ dapat meningkatkan sistem imunnya dibandingkan kelompok kontrol. ${ }^{11}$ Zinc secara tidak langsung memengaruhi fungsi imun melalui peran sebagai kofaktor dalam pembentukan DNA, RNA, dan protein sehingga meningkatkan pembelahan selular. ${ }^{8,26}$ Zat besi juga memengaruhi imunitas humoral dan selular. Defisiensi $\mathrm{Fe}$ dapat menimbulkan depresi sistem imun terutama pada imunitas selular. ${ }^{8,12}$

Kandungan isoflavon dalam kedelai dan tempe juga dapat memperbaiki sistem imun. Sesuai dengan penelitian yang dilakukan oleh Saifulhaq yang membuktikan bahwa senyawa flavonoid dapat meningkatkan proliferasi limfosit lien mencit. ${ }^{14}$ Namun hasil penelitian ini tidak sesuai dengan penelitian yang dilakukan Sasmito et al yang menyatakan bahwa susu kedelai tidak berpengaruh terhadap imunitas selular tetapi berpengaruh terhadap imunitas humoral. ${ }^{13}$ Penelitian Sasmito menggunakan hewan uji yang diinduksi hepatitis A dan serum diambil pada hari ke 14, 35 dan 46 untuk penetapan kadar IgG dan IgA. Isolasi limfosit dari limpa untuk mengetahui proliferasinya dilakukan pada hari ke-46. Virus dapat ditemukan ekstraselular pada awal infeksi sebelum masuk ke dalam sel atau virus sitopatik yang dilepas oleh sel terinfeksi yang dihancurkan. ${ }^{2}$ Alasan tersebut yang menjadi kemungkinan hanya terjadi peningkatan pada imunitas humoral pada mencit diinduksi hepatitis A yang diberi susu kedelai.

Hasil penelitian ini menunjukkan bahwa tidak terdapat perbedaan yang bermakna $(\mathrm{p}=0,772)$ hitung limfosit total antara kelompok $\mathrm{C}$ yang diberi emulsi kedelai dengan kelompok D yang diberi emulsi tempe. Pengolahan kedelai menjadi tempe dapat menyebabkan zat-zat penghambat yang dikandungnya yaitu inhibitor protease dan asam fitat menjadi berkurang karena digantikan oleh protease dan fitase. ${ }^{9,16,17}$ Enzim tersebut meningkatkan bioavailabilitas protein dan mineral. Bioavailabilitas asam amino arginin meningkat $3,7 \%$ dan mineral Ca meningkat $16,6 \% .{ }^{27}$ Namun kandungan nutrisi tempe berkurang dibanding dengan kedelai. Protein yang dikandung kedelai adalah 36,5\% sedangkan protein yang dikandung tempe adalah $19 \%$. Isoflavon yang dikandung kedelai adalah $200 \mathrm{mg}$ sedangkan tempe mengandung $53 \mathrm{mg}$ isoflavon. Kandungan $\mathrm{Zn}$ dan Fe pada kedelai berturut-turut adalah 4,9 mg dan 15,7 mg sedangkan pada tempe adalah $1,81 \mathrm{mg}$ dan $2,3 \mathrm{mg} .{ }^{28}$ Kandungan nutrisi tepung tempe juga masih setara dengan tempe yang mentah. ${ }^{29}$ 
Penurunan kandungan nutrisi tersebut dapat disebabkan oleh proses pengolahan pada kedelai. Pembuatan kedelai menjadi tempe meliputi pencucian, perebusan pertama, perendaman, pengupasan kulit, pemisahan kulit dan pencucian, perebusan kedua, penirisan, pemberian ragi, pembungkusan dan pemeraman tempe. ${ }^{30}$ Perendaman kedelai menyebabkan lepasnya ikatan struktur protein sehingga komponen protein terlarut dalam air. ${ }^{31}$ Protein juga akan terdenaturasi jika dipanaskan pada suhu $60-90^{\circ} \mathrm{C}$ selama satu jam atau kurang. ${ }^{32}$ Proses fermentasi juga bersifat proteolitik yang akan mendegradasi protein menjadi dipeptida dan seterusnya menjadi senyawa $\mathrm{NH}_{3}$ atau $\mathrm{N}_{2}$ yang hilang melalui penguapan. ${ }^{33}$

Perbandingan antara kedelai yang memiliki kandungan nutrisi tinggi namun memiliki zat-zat penghambat dengan tempe yang memiliki kandungan nutrisi lebih rendah namun memiliki zatzat yang membantu pencernaan dan penyerapan nutrisi menjadi lebih baik, maka kemungkinan alasan tersebut yang menyebabkan tidak terdapat perbedaan bermakna pada hitung limfosit total antara kelompok tikus yang diberi emulsi kedelai dengan yang diberi emulsi tempe.

\section{KESIMPULAN}

Dari hasil penelitian di atas dapat disimpulkan bahwa tempe dan kedelai berpotensi dalam meningkatkan sistem imun melalui peningkatan hitung limfosit total. Namun, dalam jumlah yang sama, tidak terdapat perbedaan efek yang signifikan dari emulsi tepung tempe dibandingkan dengan emulsi tepung kedelai terhadap peningkatan hitung limfosit total pada hewan coba. Hal ini diduga akibat proses pengolahan kedelai menjadi tempe yang menyebabkan berkurangnya kadar zat-zat gizi tertentu pada tempe meskipun daya absorbsi zat gizinya lebih meningkat dibandingkan kedelai.

\section{UCAPAN TERIMA KASIH}

Penelitian ini merupakan skripsi yang penulis ajukan sebagai syarat untuk memperoleh gelar Sarjana Kedokteran di Fakultas Kedokteran Universitas Riau. Penulis mengucapkan terima kasih kepada dr. Imelda T Pardede, M.Gizi dan dr. Huriatul Masdar M.Sc selaku dosen pembimbing I dan II yang telah memberikan waktu, pikiran, perhatian, ilmu, nasihat serta motivasi kepada penulis dalam pembuatan tugas akhir ini. Penulis juga mengucapkan terima kasih kepada semua pihak yang telah membantu dan telah mendoakan suksesnya penelitian ini.

\section{DAFTAR PUSTAKA}

1. Kresno SB. Imunologi : Diagnosis dan prosedur laboratorium. - Ed. 3. - Jakarta: Balai Penerbit FKUI, 2000.

2. Baratawidjaja KG. Imunologi dasar. -Ed. 7Jakarta : Balai Penerbit FKUI, 2006.

3. Nafrialdi. Imunomodulator, imunosupresan dan imunostimulan. Dalam: Gunawan SG, Setiabudy R, Nafrialdi, Elysabeth, editor. Farmakologi dan Terapi. Jakarta: Gaya Baru; 2007. 757-68.

4. Katzung BG. Farmakologi: dasar dan klinik. Buku 2. - Ed. 1. - Jakarta: Salemba Medika, 2002.

5. Katrin, Andreanus AS, Gana SA, Soediro I. Aktivitas imunostimulan beberapa tumbuhan obat Indonesia serta isolasi dan identifikasi senyawa imunostimulan daun Dendrophthoe pentandra (L.) MIQ (disertasi). Jawa Barat: Institut Teknologi Bandung; 2005.

6. Prasetya AT. Pengaruh pemberian propolis terhadap proliferasi sel limfosit limfa (studi eksperimental mencit balb/c yang diinduksi prednison) (skripsi). Jawa Tengah: Universitas Islam Sultan Agung; 2009.

7. Usman S. Konversi BTA pada penderita TB paru kategori I dengan berat badan rendah dibandingkan berat badan normal yang mendapatkan terapi intensif (tesis). Medan: Universitas Sumatera Utara; 2008.

8. Fatmah. Respons imunitas yang rendah pada tubuh manusia usia lanjut. Makara Kesehatan. 2006;10(1):47-53.

9. Heinnerman J. Khasiat kedelai bagi kesehatan anda / John Heinnerman ; alih bahasa, Endang S; Editor, Tim Prestasi Pustakaraya. Jakarta : Prestasi Pustakaraya, 2003.

10.Harjanti RT. Pengaruh pemberian tepung kedelai terhadap kadar asam urat dalam darah tikus putih 
(skripsi). Semarang: Universitas Negeri Semarang; 2006.

11. Winarsi H, Muchtadi D, Zakaria FR, Purwanto A. Efek suplementasi $\mathrm{Zn}$ terhadap status imun wanita premenopause yang diintervensi dengan minuman berisoflavon. Hayati. 2005;12(2):826.

12.Suega K. Hubungan besi dan produksi sitokin. J Peny Dalam. 2006;7(2):149-58.

13.Sasmito E, Mulyaningsih S, Untari EK, Widyaningrum R. Aktivitas imunostimulan susu kedelai terhadap imunnoglobulin ( $\operatorname{IgG}, \operatorname{Ig} \mathrm{A})$ dan proliferasi sel limfosit pada mencit Balb/c yang diinduksi hepatitis A. Majalah Farmasi Indonesia. 2006;17(3):156-61.

14. Saifulhaq M. Pengaruh pemberian ekstrak buah mahkota dewa dosis bertingkat terhadap proliferasi limfosit lien pada mencit BALB/c. Biomedika. 2009; 1(2): 33-6.

15.Kusmardi, Kumala S, Wulandari D. Pengaruh pemberian ekstrak etanol daun johar (Cassia siamea Lamk.) terhadap peningkatan aktivitas dan kapasitas fagositosis sel makrofag. Makara Kesehatan. 2006;10(2):89-93.

16. Astuti M, Meliala A, Dalais FS, Wahlqvist ML. Tempe, a nutritious and healthy food from Indonesia. Asia Pasific J Clin Nutr. 2000;9(4):322-5.

17.Septiani Y, Purwoko T, Pangastuti A. Kadar karbohidrat, lemak, dan protein pada kecap dari tempe. Bioteknologi. 2004;1(2):48-53.

18.Suhenti R. Pengaruh tepung tempe terhadap ukuran jaringan kanker mamma dan gambaran mikroanatomi hepar mencit (mus muscullus) galur $\mathrm{C} 3 \mathrm{H}$ setelah ditransplantasi sel adenocarcinoma mammae [skripsi]. Semarang: Universitas Negeri Semarang; 2007.

19. Stell RD, Torrie JH. Principle and procedur of statistic a biometrical approach. Tokyo: MC Graw Hill, 1990.

20.Triana E, Nurhidayat N. Pengaruh pemberian beras yang difermentasi oleh Monascus purpureus Jmba terhadap darah tikus putih (Rattus sp.) hiperkolesterolemia. Biodiversitas.
2006;7(4):317-321.

21. Ardianto B, Sumadiono, Sutaryo. Jumlah limfosit absolut dan relatif pada infeksi dengue. Berkala Ilmu Kedokteran. 2002;34(4):221-9.

22.Dahlan MS. Statistika untuk kedokteran dan kesehatan: uji hipotesis dengan menggunakan SPSS. Jakarta: Arkans, 2004.

23.Fouhil AFIE, Turkall RM. Effect of alternate-day hydrocortisone therapy on the immunologically immature rat. I: effect on blood cell count, immunoglobulin concentrations, and body and organ weights. Toxicologic Pathology. 1993;21(4):377-82.

24.Arifah S, Purwanti OS. Pengaruh pemberian epineprin dan hidrokortison terhadap jumlah dan diameter germinal center kelenjar getah bening tikus putih jantan Wistar. Berita Ilmu Keperawatan. 2008;1(3):101-6.

25.Lanza L, Scudeletti M, Puppo F, Bosco O, Peirano L, Filaci G et al. Prednisone increases apoptosis in in vitro activated human peripheral blood T lymphocytes. Clin Exp Immunol. 1996;103:482-90.

26. Hidayat M, Budiman I, Primana DA. Peran Zn dalam terjadinya acne vulgaris. Jurnal Kedokteran Maranatha. 2008;7(2):145-155.

27. Marlida Y, Periadnadi, Delfita R. Isolasi dan karakterisasi enzim phytase mikroflora endofitik tanaman kedelai (Glycine max L.). Universitas Andalas.

28.USDA Nutrient Database for Standard Reference. [Dikutip 10 Desember 2009] Diakses dari: http:/ /www.nal.usda.gov/fnic/cgi-bin/nut search.pl

29. Afrisanti DW. Kualitas kimia dan organoleptik nugget daging kelinci dengan penambahan tepung tempe [skripsi]. Surakarta: Universitas Sebelas Maret; 2010.

30.Supriyono. Memproduksi tempe. Bagian Pengembangan Kurikulum Direktorat Pendidikan Menengah Kejuruan Departemen Pendidikan Nasional, 2003.

31.Sundarsih, Kurniaty Y. Pengaruh waktu dan suhu perendaman kedelai pada tingkat kesempurnaan ekstraksi protein kedelai dalam proses pembuatan 
tahu [makalah penelitian]. Semarang: Universitas Diponegoro; 2009.

32.Nurhidajah, Anwar S, Nurrahman. Daya terima dan kualitas protein in vitro tempe kedelai hitam (Glycine soja) yang diolah pada suhu tinggi (tesis). Jawa Tengah: Universitas Diponegoro; 2008.
33.Deliani. Pengaruh lama fermentasi terhadap kadar protein, lemak, komposisi asam lemak dan asam fitat pada pembuatan tempe (tesis). Medan: Universitas Sumatera Utara; 2008. 


\section{Petunjuk bagi Penulis Jurnal Ilmu Kedokteran (JIK) Journal of Medical Science}

1. Artikel yang ditulis untuk dimuat di Jurnal Ilmu Kedokteran (JIK) meliputi hasil penelitian, tinjauan pustaka dan laporan kasus di bidang kedokteran. Naskah diketik dengan huruf Times New Roman, ukuran 12 pts, dengan menggunakan spasi ganda (double), dicetak pada kertas A4 sepanjang maksimum 20 halaman, diserahkan dalam bentuk print-out sebanyak 3 eksemplar beserta soft copy-nya. Tulisan dibuat dalam format Microsoft Word. Pengiriman berkas dapat juga dilakukan melalui email sebagai attachment file yang dikirimkan ke alamat: jik bpk@ya-hoo.com

2. Nama penulis artikel dicantumkan tanpa gelar akademik dan ditempatkan di bawah judul artikel. Institusi asal penulis serta alamat coresponding author dapat dicantumkan pada catatan kaki.

3. Artikel ditulis dalam bahasa Indonesia atau Inggris dengan format esai, disertai judul pada masingmasing bagian artikel, kecuali bagian pendahuluan yang disajikan tanpa judul bagian. Judul artikel dicetak dengan huruf besar kecil tepi kiri, dengan huruf sebesar 14 poin. Peringkat judul bagian dinyatakan dengan huruf yang berbeda (semua judul bagian dan sub-bagian dicetak tebal atau tebal miring), dan tidak menggunakan angka/nomor pada judul bagian:

\section{PERINGKAT 1 (HURUF BESAR SEMUA, TEBAL, RATA TEPI KIRI)}

\section{Peringkat 2 (Huruf Besar kecil, Tebal, Rata Tepi Kiri) \\ Peringkat 3 ( Huruf Besar Kecil, Tebal-Miring, Rata Tepi Kiri)}

4. Sistematika artikel Tinjauan Pustaka (Jurnal Review) adalah: Judul; nama penulis (tanpa gelar akademik); abstrak (maksimum 100 kata); kata kunci; pendahuluan (tanpa judul) yang berisi latar belakang dan tujuan atau ruang lingkup tulisan; bahasan utama (dapat dibagi ke dalam beberapa sub-bagian); penutup atau kesimpulan; daftar rujukan (hanya memuat sumber-sumber yang dirujuk).

5. Sistematika artikel hasil penelitian adalah: judul; nama penulis (tanpa gelar akademik); abstrak (maksimum 150 kata) yang berisi tujuan, metode, hasil penelitian dan kesimpulan; kata kunci; pendahuluan (tanpa judul) yang berisi latar belakang, sedikit tinjauan pustaka, dan tujuan penelitian; metode; hasil; pembahasan; kesimpulan; ucapan terima kasih dan daftar rujukan(hanya memuat sumber-sumber yang dirujuk).

6. Sistematika laporan kasus adalah judul, abstrak, nama penulis (tanpa gelar akademik), laporan kasus, pembahasan, kesimpulan dan daftar rujukan

7. Sumber rujukan sedapat mungkin merupakan pustaka-pustaka terbitan 10 tahun terakhir. Rujukan yang diutamakan adalah sumber-sumber primer berupa laporan penelitian (termasuk skripsi, tesis, disertasi) atau artikel-artikel penelitian dalam jurnal dan/atau majalah ilmiah.

8. Perujukan dan pengutipan ditulis sesuai aturan Vancouver, diberi nomor urut sesuai dengan urutan pemunculan dalam keseluruhan teks, bukan menurut abjad. Cantumkanlah nama semua penulis bila tidak lebih dari 6 orang; bila lebih dari 6 orang penulis, tulis nama 6 penulis pertama diikuti et al. Jumlah rujukan sebaiknya dibatasi sampai 25 buah. Gunakan contoh yang sesuai dengan edisi ke 5 dari Uniform Requirements for Manuscript Submitted to Biomedical Journals yang disusun oleh International Commitee of Medical Journal Editors, 1977. Singkatan nama jurnal disesuaikan dengan Index Medicus. Hindarilah penggunaan abstrak sebagai rujukan. 
Untuk materi yang sudah dikirim untuk publikasi namun belum diterbitkan harus dirujuk dengan menyebutkannya sebagai pengamatan yang belum dipublikasi (Unpublished observation) seizin sumber. Makalah yang telah diterima namun belum terbit, dapat dirujuk dengan mencantum kata "in press".

9. Berikut adalah contoh cara menuliskan rujukan

\section{A Artikel standar}

Allen KJ, Soriano HE. Liver cell transplantation: the road to clinical application. J Lab Clin Med 2001;138:298-312.

Artikel yang lebih dari 6 penulis:

Block GD, Locker J, Bowen WC, Petersen BE, Katyal S, Strom SC, et al. Population expansion, clonal growth, and specific differentiation patterns in primary cultures of hepatocytes induced by HGF/SF, EGFand TGF alpha in a chemically defined (HGM) medium. J Cell

Biol1996;132:1133-1149.

Volume dalam suplemen

Iqbal K, Grundke-Iqbal I. Elevated levels of tau and ubiquitin in brain and cerebro-spinal fluid in Alzheimer's disease. Int Psychogeriatr 1997;9(Suppl. 1):289- 96.

\section{B Buku}

Penulis perseorangan

Murray CJL, Lopez A. The global burden of disease. Cambridge:Harvard University Press, 1996.

Editor sebagai penulis

Hilt W, Wolf DH, editors. Proteasomes: the world of regulatory proteolysis. George-town, Texas: Landes Bioscience;2000. p.1- 391.

Bab dalam buku

Bulatao RA, Stevens PW. Estimates and projections of mortality by cause: a global overview, 1970-2015. In: Jamieson DT, Mosley WH, Eds. Evolving health sector priorities in developing countries. Washington: Population, Health and Nutrition Division, The World Bank, 1989.

Organisasi sebagai penulis

The World Bank. World Development Report 1993. Investing in health. New York: Oxford University Press, 1993.

\section{Disertasi/ Tesis/ Skripsi}

Kaplan SJ. Post-hospital home health care: the elderly/access and utilization (disertasi). St. louis (MO): Washington Univ.; 1995

\section{Artikel dari Internet}

Morse SS. Factors in the emergence of infectious diseases. Emerg Infect Dis (serial online) 1995 Jan-Mar (dikutip 5 Juni 1995);1(1):[24 screen]. Available from: URL: HYPERLINK http: // www.cdc.gov/incidod/eid.htm

10. Tata cara pengutipan, rujukan, tabel, dan gambar mengikuti ketentuan dalam buku PEGANGAN: Gaya Penulisan, Penyuntingan dan Penerbitan Karya Ilmiah Indonesia karya Mien A. Rifai (2005) atau mencontoh tata cara yang digunakan dalam artikel yang telah dimuat. Penulisan istilah Bahasa Indonesia sesuai dengan Pedoman Umum Ejaan Bahasa Indonesia yang Disempurnakan (Depdikbud, 1987). Artikel berbahasa Inggris menggunakan ragam baku. 
11. Semua naskah ditelaah secara anonim oleh mitra bestari (reviewers) yang ditunjuk oleh penyunting menurut bidang kepakarannya. Penulis diberikan kesempatan untuk memperbaiki naskah atas dasar rekomendasi/saran dari mitra bestari atau penyunting. Kepastian pemuatan atau penolakan naskah akan diberitahukan secara tertulis.

12.Pemeriksaan dan penyuntingan cetak-coba dikerjakan oleh penyunting dan/atau dengan melibatkan penulis. Artikel yang sudah dalam bentuk cetak-coba dapat dibatalkan pemuatannya oleh penyunting jika diketahui bermasalah.

13.Segala sesuatu menyangkut perijinan pengutipan atau penggunaan software komputer untuk pembuatan naskah atau ihwal lain yang terkait dengan HAKI yang dilakukan oleh penulis artikel, berikut konsekuensi hukum yang mungkin timbul karenanya, menjadi tanggung jawab penulis artikel tersebut.

14.Sebagai prasyarat bagi pemrosesan artikel, para penyumbang artikel wajib menjadi pelanggan minimal selama setahun. Penulis yang artikelnya dimuat wajib membayar kontribusi biaya cetak sebesar Rp. 250.000,00 (dua ratus lima puluh ribu rupiah) perjudul. Sebagai imbalannya, penulis menerima nomor bukti pemuatan sebanyak 2 (dua) eksemplar dan cetak lepas sebanyak 2 (dua) eksemplar. Artikel yang tidak dimuat tidak akan dikembalikan, kecuali atas permintaan penulis.

Makalah dapat dikirimkan kepada:

Penyunting/Editor Jurnal Ilmu Kedokteran

Jl. Diponegoro No. 1

Pekanbaru 28111

Indonesia 